\title{
Determinants influencing the amount of asbestos-cement roofing in Poland
}

\begin{abstract}
Because of its harmfulness to human health, asbestos has been banned in 55 countries, including the EU. In Poland, the use and production of asbestos and asbestos-containing products has been forbidden since 1997. However, there is no precise data about the amount of asbestoscontaining products to be eliminated from the territory of Poland. This survey aims to identify characteristics that have a significant impact on the estimation of asbestos-containing products used in Poland. Statistical correlation between the results of the physical inventory count done in 155 municipalities was examined. As a result of the survey it was found that the amount of asbestos-cement roofing depends on the following factors: the number of individual farms in the village, the distance from the asbestos manufacturing plants, the age of the buildings and the economic situation of municipality. The results obtained may contribute to the ability to predict the amount of asbestos-containing products used in other municipalities.
\end{abstract}

Keywords

Asbestos • asbestos-containing products • GIS • monitoring • asbestos removal process $\cdot$ Poland

(C) University of Warsaw - Faculty of Geography and Regional Studies
Ewa Wilk',2, Małgorzata Krówczyńska ${ }^{1,2}$, Piotr Pabjanek ${ }^{1}$

1Department of Geoinformatics,

Cartography and Remote Sensing,

Faculty of Geography and Regional Studies,

University of Warsaw, Poland;

2WGS84 Polska Sp. z o.o., Milanówek, Poland

e-mail: ewa.wilk@student.uw.edu.pl; mkrowczynska@uw.edu.pl; p.pabjanek@uw.edu.pl

Received: 25 September 2014

Accepted: 22 July 2015
Introduction

The term asbestos covers chrysotile (white asbestos), amosite (brown asbestos), crocidolite (blue asbestos), tremolite, anthophyllite and actinolite (Ross et al. 2007). A unique set of physical and chemical properties has led to many industrial applications for asbestos (Virta 2002, 2003) For example: as roof coatings (flat and corrugated sheets), pipes, flooring (Dunnigan 1993), water supply pipes, textiles, rope, cord and yarn, paper, friction and compound materials, household products, plastic fillers (Alleman \& Mossman 1997), as well as clutches, brake linings, gaskets and pads for automobiles (Thompson \& Mason 2002).

Exposure to asbestos can cause a wide range of diseases such as lung cancer, mesothelioma and asbestosis (Outline for the Development of National Programmes for Elimination of Asbestos-Related Diseases 2007). In 1969, asbestos was classified by the International Agency for Research on Cancer as being carcinogenic to humans (IARC 1987). In order to eliminate asbestos-related diseases, the World Health Organization and the International Labour Organization have strongly recommended stopping the use of all types of asbestos (WHO 2006). The production and use of asbestoscontaining materials has been banned in 55 countries (LaDou et al. 2010; International Ban Asbestos Secretariat 2014), including, from 1 January 2005, all EU countries (Commission Directive 1999/77/EC).

In Poland, according to the Act of 19 June 1997 banning the use of asbestos-containing products (Act of 19 June 1997 on the prohibition of the use of asbestos-containing products) and the amending Ordinance of the Minister of Economy of 13 December 2010 (Ordinance of the Minister of Economy of 13 December 2010), asbestoscontaining products should be safely eliminated by the end of 2032. In the Programme for Asbestos Abatement in Poland 2009-
2032, it was estimated that about 14.5 million tons of asbestoscontaining products are to be removed from the territory of Poland (Resolution No. 39/2010 of the Council of Ministers). Since these estimations need to be validated, municipalities should collect data on the quantity of asbestos-containing products. This is mainly done through a physical count, a timeconsuming and labour-intensive process (Krówczyńska \& Wilk 2013). Therefore it is essential to develop methods for assessing the amount of asbestos-containing products used in Poland based on the different data sources that are available.

The vast majority of asbestos-containing products are in the form of asbestos-cement roofing and building construction materials (Collegium Ramazzini 2010). There have been several surveys undertaken on asbestos identification with the use of hyperspectral remote sensing data for a certain region, part of the country or city, in order to estimate the quantity of asbestos products in the study area (Fiumi et al. 2012; Giannini et al. 2012; Frassy et al. 2014; Szabo et al. 2014).

The survey undertaken aims to identify characteristics that might have an influence on the estimation of amount of asbestoscement roofing. Statistical characteristics were predetermined taking into consideration the physical count in 155 municipalities in Poland (the lowest level of territorial division in the country). It was assumed that there is a statistical relationship between the amount of asbestos-cement roofing used and the number of farms, the financial and organizational efficiency of municipalities, the economic situation of the inhabitants and the distance from the asbestos manufacturing plants. The objective of the undertaken study is to examine the statistical correlation between 
the physical count inventory results, the proximity of the asbestos manufacturing plants and appropriately selected statistical data by determining the degree of correlation.

\section{Methods}

The input data consisted of data gathered during the field survey on asbestos-containing products physical count, undertaken in 155 municipalities; survey of asbestos manufacturing plants in Poland; data on the type of building derived from land use maps; and statistical data provided by the Central Statistical Office.

The asbestos-cement roofing physical count in 155 municipalities in Poland

The physical counting of asbestos-containing products was performed over the period 2008-2013 by the company WGS84 Polska Sp. z o.o. in 155 municipalities (out of a total of 2,479 in Poland) spread throughout Poland. It was conducted during site visits with the use of orthophotomap printouts in the scale of $1: 2500$. Field survey inspectors acquired the following data: location (street names, building numbers), asbestos materials (type, quality and amount), and building features (the degree of the slope of the roof, and the function of the building). The selected features were assigned to each asbestos object by a dedicated signature on the orthophotomap printout. Such collected primary data was then processed with the use of GIS software in order to obtain spatially referenced data (Goodchild \& Haining 2004). As a result of the field survey and digital data referencing, a database has been developed (Table 1).

Data on asbestos manufacturing plants in Poland

In 2013, data on asbestos manufacturing plants in Poland was collected and analysed by the authors. In Poland there were 29 asbestos manufacturing plants. Based on survey questionnaires, in-depth interviews and field surveys, the geodatabase for asbestos manufacturing plants was developed by assigning all of the following attributes to each plant: the name of the plant according to Annex 4 to the Act of 19 June 1997 on the prohibition of the use of products containing asbestos, the actual address details, data on historical production, information on change of ownership, the current owner of the premises, the spatial location of the plant, the type of economic activity actually conducted, the impact of the plant on the environment, the impact of the plant on the health of residents, the condition of the buildings, asbestos elimination carried out, the use of asbestos-containing products and up-to-date photographs. The survey undertaken by authors covered all the asbestos manufacturing plants in Poland.

\section{Statistical data and survey}

The statistical data was acquired through Local Data Bank provided by the Central Statistical Office (Local Data Bank 2012). In total, 18 features have been tested, which refer to the characteristics of buildings, the social-economic situation in Poland and the proximity of asbestos manufacturing plants. Among these characteristics the following items should be enumerated:

1. Characteristics of buildings: inhabited dwellings per $\mathrm{km}^{2}$ (by year of building construction: before 1918, 1918-1944, 1945-1970, 1971-1978, 1979-1988, 1989-2002), households with occupant, using an individual agricultural holding per $\mathrm{km}^{2}$,

2. Municipalities' social-economic situation: expenses per one inhabitant, financial resources for supporting the activities of non-budgetary sources per $\mathrm{km}^{2}$, funds from the European Union budget per $\mathrm{km}^{2}$, financing and co-financing of EU
Table 1. Asbestos-cement materials database attributes

\begin{tabular}{|c|c|}
\hline No. & Feature \\
\hline 1 & Street names \\
\hline 2 & Building numbers \\
\hline 3 & Type of asbestos-cement materials \\
\hline 4 & Degree of the slope of the roof \\
\hline 5 & Condition/quality of asbestos-cement materials \\
\hline 6 & Function of the building \\
\hline 7 & Amount of asbestos-cement materials used \\
\hline
\end{tabular}

Table 2. The correlation between the total amount of asbestoscontaining products and the area covered by the types of building in the municipality ( $n=155)$, Spearman Rank Correlation Coefficient $r_{s}$ (bold indicates a significant correlation)

\begin{tabular}{|c|c|c|}
\hline $\begin{array}{c}\text { Type of building } \\
\text { environment }\end{array}$ & $\boldsymbol{r}_{\boldsymbol{s}}$ & $\boldsymbol{p}$-value < \\
\hline village & $\mathbf{0 . 3 1 1}$ & 0.000082 \\
\hline dense urban & 0.053 & 0.516349 \\
\hline industrial & $\mathbf{- 0 . 2 3 7}$ & 0.002928 \\
\hline large buildings & $\mathbf{- 0 . 2 1 4}$ & 0.007396 \\
\hline suburban & 0.114 & 0.156523 \\
\hline
\end{tabular}

programs and projects per $\mathrm{km}^{2}$, general subsidy per $\mathrm{km}^{2}$, communal economy expenditure in total per $\mathrm{km}^{2}$, agricultural expenditure per $\mathrm{km}^{2}$, registered unemployed per $\mathrm{km}^{2}$, internal and international migration per $\mathrm{km}^{2}$,

3. Number of asbestos manufacturing plants within a radius of $100 \mathrm{~km}$ and the distance from the asbestos manufacturing plant to the municipality's centre (centroid).

In order to avoid the area of the municipalities influencing the conducted analysis, the amount of asbestos-cement roofing expressed in $\mathrm{m}^{2}$ was converted to per hectare of the area of municipality. This was the dependent variable. The Spearman Rank Correlation Coefficient $r_{s}$ was calculated (Croux \& Dehon 2010). Calculations were performed with the use of STATISTICA 10 software (StatSoft, Inc. 2011).

Results

The amount of asbestos-cement roofing expressed in $\mathrm{m}^{2}$ is characterized by a high volatility. It varies from 1.7 to $95.7 \mathrm{~m}^{2} / \mathrm{ha}$. Of the total results, $80 \%$ lie between 4.7 and 48.5 (percentile 10 and 90 respectively), with a mean value of 23.6 and a standard deviation of $18.2 \mathrm{~m}^{2} / \mathrm{ha}$. The distribution is heavily skewed to the right and dominated by municipalities with small amounts of asbestos-containing products. The total amount of asbestoscement roofing in municipalities is positively correlated with rural areas (village), and negatively with industrial, transport and large buildings (Table 2, Figure 1).

The amount of asbestos-cement roofing is correlated primarily with the number of farms $\left(r_{s}=0.587\right)$. Positive correlation has been demonstrated for buildings built from 1945 to 1970 with $r_{s}$ amounting to 0.392 . The distance from the asbestos manufacturing plants producing asbestos roofing $\left(r_{s}=0.402\right)$ is of great importance (Figure 2). 


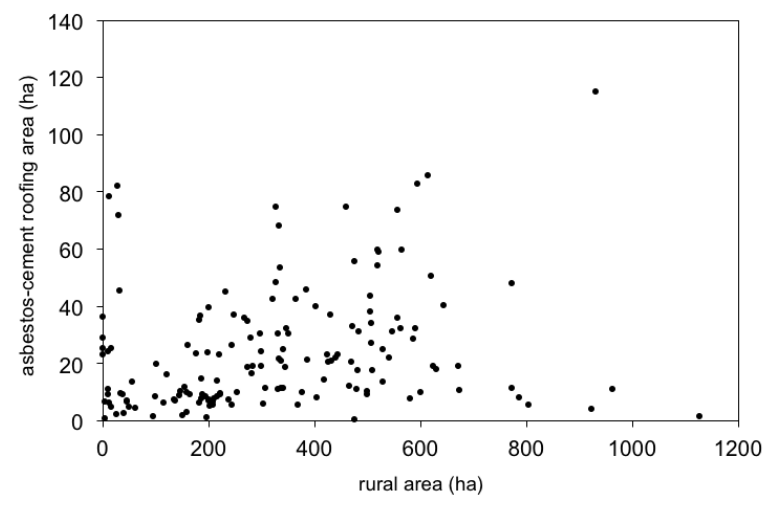

Figure 1. The correlation between the total area of asbestoscontaining products (ha) and rural area (ha)
What is noteworthy is that only a few characteristics concerning the social and economic situation of municipalities are crucial for the conducted analysis; they include general subsidy or other subsidies from the central budget (Table 3).

\section{Conclusions}

The amount of asbestos-cement roofing reveals a high correlation with the tested features. The highest positive correlation is related to the number of individual farms. Hence, it is to be expected that more asbestos-cement roofing is located in rural areas in buildings constructed between 1945 and 1970. After World War II there were many buildings in Poland that were damaged and some of also destroyed. Many of these buildings were roofed with asbestos-cement roofing during reconstruction. From 1945-1970 there were many farm buildings that were covered with straw and since it is flammable, there were many buildings that burnt down during storms. It resulted in replacing the roofing with asbestos-cement products as it was incombustible and the roof trusses were suitable for such material. It is also

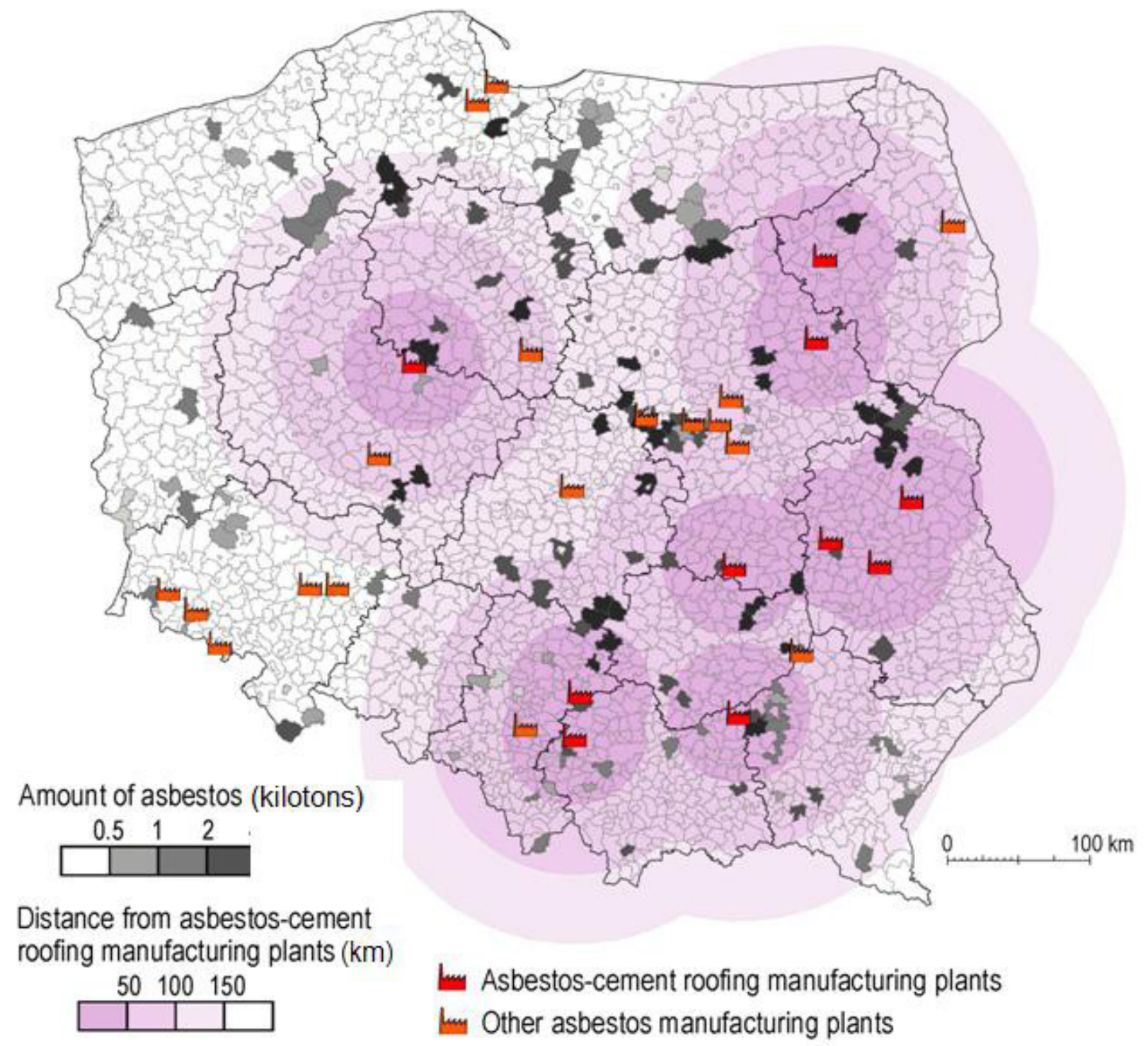

Figure 2. Asbestos-cement roofing physical count results for 155 municipalities and the proximity of asbestos manufacturing plants in Poland 
Table 3. The relationships between the amount of asbestos-containing products used per ha, and the characteristics of municipalities (converted to $\mathrm{km}^{2}$ of the area) expressed by the Spearman Rank Correlation Coefficient $r_{s}$, for each attribute $n=155$, correlations that are statistically significant $(p<0.05)$ are indicated

\begin{tabular}{|c|c|c|}
\hline Feature & $r_{s}$ & $p$-value $<$ \\
\hline household with the use of a farm per $\mathrm{km}^{2}$ & 0.587 & 0.000000 \\
\hline apartment building before 1918 per km² & -0.410 & 0.000000 \\
\hline apartment building 1918-1944 per km² & -0.310 & 0.000087 \\
\hline apartment building $1945-1970$ per km² & 0.392 & 0.000000 \\
\hline apartment building 1971-1978 per km² & 0.301 & 0.000140 \\
\hline apartment building 1979-1988 per km² & 0.261 & 0.001057 \\
\hline apartment building 1989-2002 per km² & 0.266 & 0.000830 \\
\hline expense per 1 citizen & -0.225 & 0.004832 \\
\hline financial resources for supporting the activities of non-budgetary sources per $\mathrm{km}^{2}$ & 0.074 & 0.362867 \\
\hline funds from the European Union budget per $\mathrm{km}^{2}$ & -0.044 & 0.587564 \\
\hline financing and co-financing of EU programs and projects per $\mathrm{km}^{2}$ & -0.029 & 0.718554 \\
\hline the general subsidy per $\mathrm{km}^{2}$ & 0.295 & 0.000191 \\
\hline communal economy expenditure in total per $\mathrm{km}^{2}$ & 0.007 & 0.932573 \\
\hline expenditure on agriculture per $\mathrm{km}^{2}$ & 0.131 & 0.103831 \\
\hline registered unemployed per $\mathrm{km}^{2}$ & 0.050 & 0.539535 \\
\hline internal and international migration per $\mathrm{km}^{2}$ & 0.081 & 0.318763 \\
\hline number of asbestos manufacturing plants within a radius of $100 \mathrm{~km}$ & 0.402 & 0.000000 \\
\hline $\begin{array}{l}\text { distance from the asbestos manufacturing plant to the municipality centre } \\
\text { (centroid) }\end{array}$ & -0.431 & 0.000000 \\
\hline
\end{tabular}

relevant that the correlation between the amount of asbestoscement roofing and building construction period is weaker for each surveyed period (the weakest is observed for 1989-2002). It might be explained by the fact that in 1997 there was cessation of asbestos production executed, the nearer to 1997, the less asbestos products were manufactured. For historic buildings (older than 100 years) negative correlation was denoted, as they are mainly covered with ceramic roof tiles; no additional reconstruction work is allowed to be undertaken without permission from the Office of National Historic Buildings. A high correlation was also observed between the amount of asbestoscement roofing and the proximity of the asbestos manufacturing plants. The social-economic condition of municipalities also has an impact on the amount of asbestos-cement roofing used in building construction (more asbestos-cement roofing is used in low income municipalities described by higher subsidies and lower spending by the municipality budget per capita). The society's wealth affects a recognition for the need for building redecoration. The less wealthy a society is, the less able they are to afford the replacement of asbestos roofing with a new material that would not be harmful to their health. The significant influence of the factor concerning the asbestos manufacturing plants distance can be explained by the political regime in Poland before 1989 , in which the command-and-control economy introduced a special distribution system where, due to the scarcity of roofing materials, it was easier to acquire asbestos-cement roofing within the proximity of asbestos manufacturing plants.

The amount of asbestos-cement roofing used in Poland depends on the following features: the number of individual farms in the village, the distance from asbestos manufacturing plants, the age of the buildings and the economic situation of the municipality. The results obtained may contribute to the prediction of the amount of asbestos-containing products used in other municipalities not yet analysed.

\section{References}

Act of 19 June 1997 on the prohibition of the use of asbestoscontaining products, 1997, Journal of Laws No 101, item 628 as amended.

Alleman, JE \& Mossman, BT 1997, 'Asbestos revisited', Scientific American, vol. 277, pp. 70-75.

Collegium Ramazzini, 2010, 'Asbestos is still with us: repeat call for a universal ban', Odontology, vol. 98, pp. 97-10.

Commission Directive 1999/77/EC of 26 July 1999 adapting to technical progress for the sixth time Annex I to Council Directive 76/769/EEC on the approximation of the laws, regulations and administrative provisions of the Member States relating to restrictions on the marketing and use of certain dangerous substances and preparations (asbestos)
1999. Available from: <hhttp://eur-lex.europa.eu/legalcontent/EN/TXT/?uri=CELEX:31999L0077>. [18 September 2014].

Croux, C \& Dehon, C 2010. 'Influence functions of the Spearman and Kendall correlation measures' Statistical Methods \& Applications, vol. 19, no. 4, pp. 497-515.

Dunnigan, J 1993. 'Chrysotile asbestos revisited', British Journal of Industrial Medicine, vol. 50, pp. 862-863.

Fiumi, L, Campopiano, A, Casciardi, S \& Ramires, D 2012, 'Method validation for the identification of asbestos-cement roofing', Appl Geomat, vol. 5, pp. 55-64.

Frassy, F, Candiani, G, Rusmini, M, Maianti, P, Marchesi, A, Nodari, FR, Via, GD, Albonico, C \& Gianinetto, M 2014 
'Mapping Asbestos-Cement Roofing with Hyperspectral Remote Sensing over a Large Mountain Region of the Italian Western Alps', Sensors, vol. 14, no 9, pp. 15900-15913.

Giannini, MB, Creta, T, Guglietta, D, Merola, P \& Allegrini A 2012, 'Methodologies to identify asbestos-cement roofing by remote data', Italian Journal of Remote Sensing, vol. 44, pp. 27-37.

Goodchild, MF \& Haining, RP 2004, 'GIS and spatial data analysis: Converging perspectives', Papers in Regional Science, vol. 83, no. 1, pp. 363-385.

IARC Monographs on the Evaluation of the Carcinogenic Risks to Humans. Supplement 7: Asbestos 1987, International Agency for Research on Cancer, pp. 106-116.

International Ban Asbestos Secretariat 2014. Available from: <http://www.ibasecretariat.org/lka_alpha_asb_ban_280704. php>. [30 January 2014].

Krówczyńska, M \& Wilk, E 2013, 'Aerial imagery and geographic information systems used in the asbestos removal process in Poland', in 33th EARSeL Symposium Towards Horizon 2020: Earth Observation and Social Perspectives, ed. R Lasaponara, N Masini \& M Biscione, EARSeL, Matera, pp. 823-828.

LaDou, J, Castleman, B, Frank, A, Gochfeld, M, Greenberg, M, Huff, J, Joshi, TK, Landrigan, PJ, Lemen, R, Myers, J, Soffritti, M, Soskolne, CL, Takahashi, K, Teitelbaum, D, Terracini, B \& Watterson, A 2010, 'The Case for a Global Ban on Asbestos', Environmental Health Perspectives, vol. 118, no 7, pp. 897-901.

Local Data Bank 2012, Central Statistical Office. Available from: <http://www.stat.gov.pl/bdlen/app/strona.html?p_ name=indeks $>$. [27 January 2014].

Ordinance of the Minister of Economy of 13 December 2010 on requirements for the use of products containing asbestos and the use and cleaning of plant or equipment, which have been or are being used asbestos-containing products 2011, Journal of Laws No 8, item 528.

Ordinance of the Minister of Economy, Labour and Social Policy of 2 April 2004 on methods and conditions of safe use and removal of asbestos-containing products 2004, Journal of Laws No 71, item 649 as amended.
Outline for the Development of National Programmes for Elimination of Asbestos-Related Diseases 2007, International Labour Organization and World Health Organization. Available from: <http://www.who.int/occupational_health/ publications/Out_NPEAD_ENG.pdf>. [30 January 2014].

Programme for Asbestos Abatement in Poland 2009-2032, 2010, Ministry of Economy. Available from: <http://www.mg.gov. pl/files/upload/8380/PROGRAM_ENG.pdf>. [10 December 2013].

Ross M, Langer, AM, Nord, GL, Nolan, RP, Lee, RJ, Van Orden, D \& Addison J, 2007, 'The mineral nature of asbestos', Regulatory Toxicology And Pharmacology, vol. 52 (1 Suppl), pp. 26-30.

StatSoft, Inc., 2011. STATISTICA (data analysis software system), version 10. www.statsoft.com

Thompson, S \& Mason, E 2002, 'Asbestos: Mineral and fibers', Chemical Health And Safety, vol. 9, pp. 21-23.

Szabo, S, Burai, P, Kovacs, Z, Szabo, G, Kerenyi, A, Fazekas, I, Paladki, M, Buday, T \& Szabo, G 2014, 'Testing algorithms for the identification of asbestos roofing based on hyperspectral data', Environmental Engineering and Management Journal, vol. 143 , no 11 , pp. 2875-2880.

Virta RL, 2002, 'Asbestos: Geology, Mineralogy, Mining, and Uses 2002', USGS Open-File Report: 2002-149. Available from: <http://pubs.usgs.gov/of/2002/of02-149.pdf>. [10 December 2013].

Virta RL, 2003, 'Asbestos: Geology, Mineralogy, Mining, and Uses', U.S. Department of the Interior, U.S. Geological Survey, Open-File Report 02-149. Available from: <http:// minerals.usgs.gov/minerals/pubs/commodity/asbestos/>. [10 December 2013].

World Health Organization 2006, Elimination of asbestos-related diseases WHO/SDE/OEH/06/03. Available from: <http:// whqlibdoc.who.int/hq/2006/WHO_SDE_OEH_06.03_eng. pdf>. [10 December 2013]. 